\title{
Protein synthesis in vitro by pig blastocyst tissue before attachment
}

\author{
L. T. Jones, R. B. Heap and J. S. Perry \\ A.R.C. Institute of Animal Physiology, Babraham, Cambridge CB2 4AT, U.K.
}

In pregnancy the prolongation of the life of the CL and its secretion of progesterone normally depends upon the presence of an embryo. The embryo signals its presence by some active process, and in the pig the onset of oestrogen synthesis between Days 10 and 12 (Perry, Heap \& Amoroso, 1973; Heap, Perry, Gadsby \& Burton, 1975; Perry, Heap, Gadsby \& Burton, 1976) coincides with the time of maternal recognition of pregnancy (Dhindsa \& Dziuk, 1968). The onset of steroidogenesis precedes any permanent attachment between the trophoblast and uterine wall, as intimate contact between fetal and maternal epithelia by interlocking microvilli is not established until Day 18 . During this period the blastocyst enlarges from about $2 \mathrm{~mm}$ in diameter at Day 10 to a tubular, bilaminar structure about $1000 \mathrm{~mm}$ in length by Day 14-16. In this study we have compared the nature of protein synthesis in the elongated blastocyst before definitive attachment with that in the uterine endometrium taken from the same animal. We have also examined the effect of oestradiol-17 $\beta$ on the incorporation of leucine into blastocyst tissue proteins.

Two pregnant sows from the Institute's Large White and Landrace herd were killed by captive bolt pistol and exsanguination on Day 16 of pregnancy, and the reproductive tract was removed within $15 \mathrm{~min}$. Each horn was dissected from the mesometrium and blastocysts were flushed out by a sterile technique using Brinster's medium (Brinster, 1965) omitting bovine serum albumin, penicillin and streptomycin. Uterine flushings were centrifuged at $600 \mathrm{~g}$ for $10 \mathrm{~min}$ at $4^{\circ} \mathrm{C}$. The amount of tissue (mainly trophoblast) recovered at Day 16 of pregnancy varied from $1-4 \mathrm{~g}$ wet weight. This tissue was minced with fine scissors. Endometrium was separated from the myometrium by dissection and minced or blended (10-sec pulses, Polytron Blender) before incubation.

Trophoblast $(1 \cdot 1 \mathrm{~g})$ or endometrial tissue $(4 \mathrm{~g})$ was incubated in an equivalent volume of Medium 199 containing $20 \mu \mathrm{Ci} \mathrm{L}-\left[4,5-{ }^{3} \mathrm{H}\right]$ leucine in $0.2 \mathrm{ml}$ physiological saline. Incubations were carried out at $37^{\circ} \mathrm{C}$ for $4 \mathrm{hr}$ in a gas phase of $95 \%$ oxygen and $5 \%$ carbon dioxide. After incubation, the contents of each flask were either homogenized at $4^{\circ} \mathrm{C}$ in a Potter-Elvehjem homogenizer with a polytetrafluoroethylene pestle (trophoblast) or blended using a Polytron Blender (endometrium). A soluble fraction prepared by centrifugation of homogenates at $105,000 \mathrm{~g}$ for $1 \mathrm{hr}$ was dialysed and concentrated two-fold using 15\% w/v polyethylene glycol-6000 in Brinster's medium. Disc gel electrophoresis was carried out on $300 \mu \mathrm{l}$ concentrated supernatant in $10 \%$ sucrose containing 2 drops $0.005 \%$ bromophenol blue as tracker dye. The gel used was $7.5 \%$ polyacrylamide, $\mathrm{pH} 8 \cdot 6$, and the electrode buffer was composed of $0.72 \%$ glycine and $0.2 \%$ imidazole which was adjusted to $\mathrm{pH} 7.6$ by $\mathrm{N}-\mathrm{HCl}$. The internal diameter of the running tubes was $0.8 \mathrm{~cm}$, the running time about $2 \mathrm{hr}$, and the current $8 \mathrm{~mA}$ per tube. Gels were stained in $1 \%$ naphthalene black in $7 \%$ acetic acid, or sliced at 2 -mm intervals to determine the incorporation of $\left[{ }^{3} \mathrm{H}\right]$ leucine into proteins. After protein solubilization with $0.8 \mathrm{ml}$ Soluene (Packard Co. Ltd.) for $16 \mathrm{hr}$ at $37^{\circ} \mathrm{C}$, gel slices were counted in Unisolve (Koch-Light) scintillation fluid.

$\left[{ }^{3} \mathrm{H}\right]$ Leucine was incorporated into soluble protein by the blastocyst (trophoblast) tissue. Gel electrophoresis revealed a major component labelled in the $\beta$-glycoprotein region with an $\boldsymbol{R}_{\boldsymbol{F}}$ value of 0.27 (Text-fig. 1a). There was negligible activity in the section of the gel corresponding to albumin, or pre- or post-albumin. In the presence of oestradiol-17 $\beta$ the profile of $\left[{ }^{3} \mathrm{H}\right]$ leucine incorporation into proteins was similar to that of the control sample, though incorporation was slightly reduced when $100 \mu \mathrm{g}$ oestradiol were included in the medium. Two labelled proteins were resolved $\left(\boldsymbol{R}_{\mathrm{F}} \mathbf{0 \cdot 2}\right.$ and $0 \cdot 3$ ), but this was probably attributable to gel heterogeneity rather than a specific dose effect. Stained gels, however, showed that the major component with an $R_{F}$ value of 0.27 consisted of two 
bands incompletely resolved. One of these bands was of labile material, as indicated by its disappearance when electrophoresis was repeated after freezing and thawing the material.

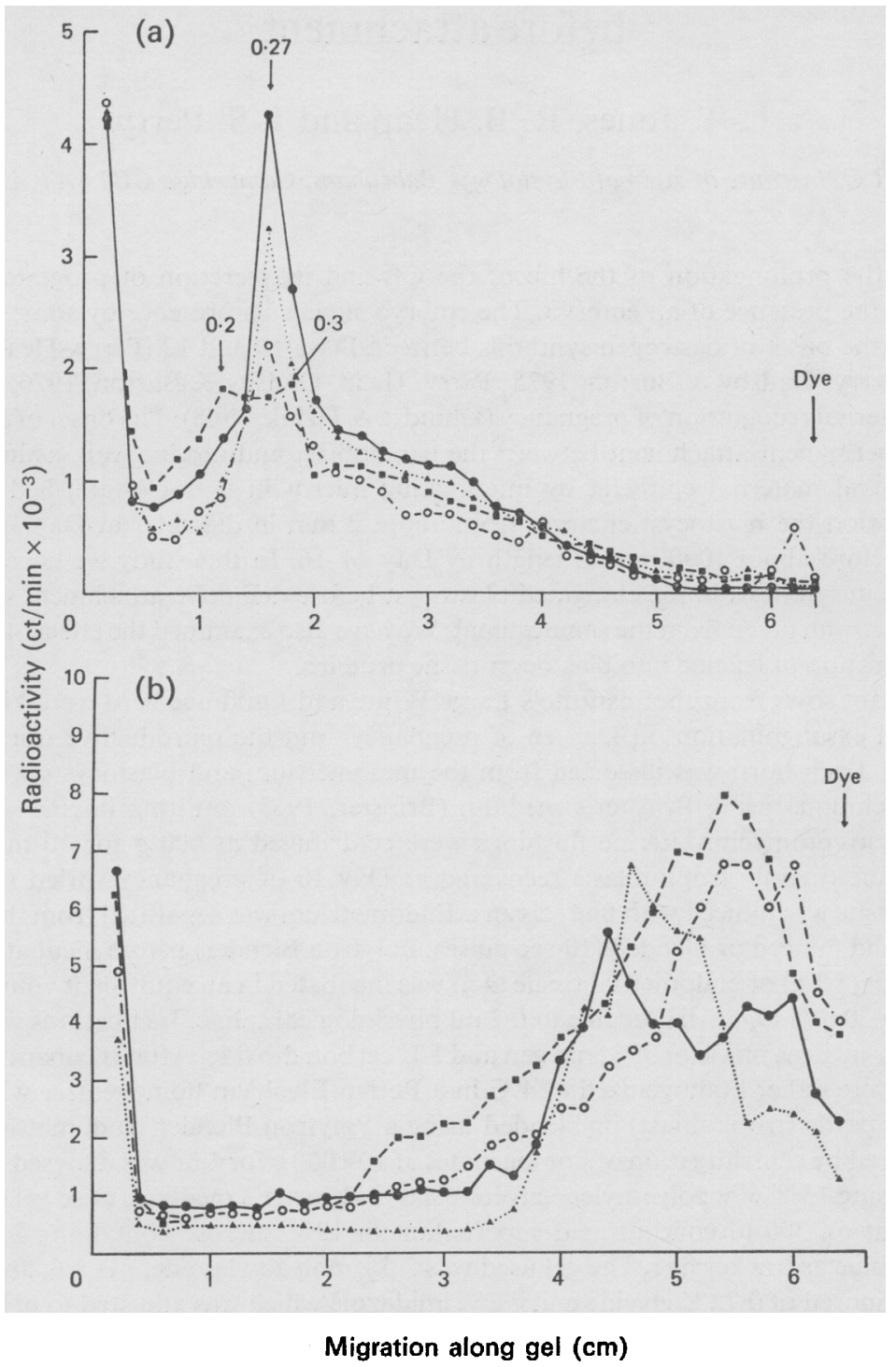

Text-fig. 1. Incorporation of $\left.{ }^{3} \mathrm{H}\right]$ leucine into soluble proteins of the (a) blastocyst (mainly trophoblast) and (b) endometrium at Day 16 of pregnancy in the pig. There was appreciable incorporation of labelled leucine into trophoblast proteins which had similar properties in gel electrophoresis to $\beta$-glycoproteins $\left(\boldsymbol{R}_{\mathrm{F}}\right.$ values $0.2,0.27$ and 0.3 ), in contrast to the incorporation into endometrial proteins in the albumin $\left(R_{\mathrm{F}}\right.$, approx. $\left.0 \cdot 8\right)$, pre- and post-albumin regions of the gel. There was no significant effect of oestradiol-17 $\beta$ on the pattern of incorporation under these experimental conditions. $\bullet$, Control; $\Lambda, 1 \mu \mathrm{g} ; \mathbf{D}, 10 \mu \mathrm{g}$; $0,100 \mu \mathrm{g}$ oestradiol-17ß.

The pattern of $\left[{ }^{3} \mathrm{H}\right]$ leucine incorporation into soluble proteins by endometrial tissue from the same animal (Text-fig. 1b) differed from that of trophoblast tissue. Endometrium from a third animal at the same stage of pregnancy was used to show that the pattern of incorporation was similar whether the tissue was blended or minced before incubation. There was a very low $\left[{ }^{3} \mathrm{H}\right]$ leucine incorporation into soluble proteins with a mobility similar to that of the two major soluble protein components 
recovered from trophoblast incubations, but a high incorporation in that part of the gel ranging from the post-albumin to the pre-albumin region. Under these experimental conditions there was no detectable effect of oestrogens on the quantitative or qualitative pattern of protein synthesis.

We thank Mr R. W. Ash and Mr J. Smith for providing experimental animals. This investigation received financial support from the World Health Organization.

\section{References}

Brinster, R.L. (1965) Studies on the development of mouse embryos in vitro. IV. Interaction of energy sources. J. Reprod. Fert. 10, 227-240.

DhindsA, D.S. \& DzIUK, P.J. (1968) Effect of pregnancy in the pig after killing embryos or fetuses in one uterine horn in early gestation. J. Anim. Sci. 27, $122-128$.

Heap, R.B., Perry, J.S., Gadsby, J.E. \& Burton, R.D. (1975) Endocrine activities of the blastocyst and early embryonic tissue in the pig. Trans. Biochem. Soc. (in press).

Perry, J.S., Heap, R.B. \& AMoroso, E.C. (1973) Steroid hormone production by pig blastocyst. Nature, Lond. 245, 45-47.

Perry, J.S., Heap, R.B., Gadsby, J.E. \& Burton, R.D. (1976) Endocrinology of the early embryo and its role in the establishment of pregnancy. J. Reprod. Fert., Suppl. 25 (in press).

Received 20 October 1975 